\title{
Rethinking Iran and International Law: The Anglo-Iranian Oil Company Case Revisited
}

\author{
Sundhya Pahuja and Cait Storr
}

\section{Introduction}

\begin{abstract}
'Il n'est guère possible d'entreprendre, à notre avis, l'étude de l'attitude de l'Iran face aux regles de droit international sans avoir présenté l'histoire des dernières décennies de ce pays. Elle explique en effet largement certaines de ses positions actuelle dans le domaine qui nos retient. Deux faits largement interdépendents on été determinants: d'une part les atteintes répétéés et sans cesse plus graves porteés a la souveraineté de l'Iran et, d'autre part, sa mise a l'écart de la communauté international jusqu'à la creation de l Société des Nations,'.
\end{abstract}

\section{Djamchid Momtaz, 'L’Iran et le Droit international' (1976)}

It seems to have long been a commonplace in the West to describe Iran as an outlaw; irredeemably defiant of international law at worst, recalcitrant at best. ${ }^{2}$ And yet like most commonplaces, the story is more complicated than it first appears. As Djamchid Momtaz observed in 1976, in an essay entitled L'Iran et le Droit International, in order even to begin to understand Iran's relationship to international law, one must have regard to historical context. In this essay, we take up the invitation to think about Iran and international law in historical context by revisiting the Anglo-Iranian Oil Company Case of 1952 through a lens we call 'historically inflected jurisprudence'. ${ }^{3}$

\footnotetext{
${ }^{1}$ Roughly translated, this reads: '(i)n our view, it would hardly be possible to undertake a study of the attitude of Iran toward the rules of international law, without having offered a study of the last decades in that country. It would largely explain several of Iran's contemporary positions in relation to the question at hand. Two largely interdependent facts have been determinative: on one hand the repeated and serious attacks on Iran's sovereignty, and on the other hand, the exclusion of Iran from the international community since the creation of the League of Nations'. D. Momtaz, 'L'Iran et le Droit International', in M-R. Djalili (ed), Aspects de la politique étrangère de l'Iran et de la France, Université de Téhéran, Centre des Hautes Etudes Internationales, 1976, p. 199.

${ }^{2}$ For an article which gives a particular example with respect to nuclear weapons, of the broader tendency in the US and UK (and elsewhere) to describe Iran as an 'outlaw' regardless of the legality of its actions, see R. Dalton, 'Iran is Not in Breach of International Law', The Guardian, June 9, 2011, available at https:/www.theguardian.com/commentisfree/2011/jun/09/iran-nuclear-power-un-threat-peace. Dalton, former British Ambassador to Iran, co-wrote the article with five other former ambassadors to Iran, including P. von Maltzahn (Germany), S. Hohwü-Christensen (Sweden), G. Metten (Belgium), F. Nicoullaud (France) \& R. Toscano (Italy).

${ }^{3}$ Anglo-Iranian Oil Company Case (United Kingdom v Iran), ICJ Reports 1952, p. 93. On historically inflected jurisprudence, see S. Pahuja, 'Letters from Bandung: Encounters with Another Inter-National Law,' in L. Eslava, M. Fakhri \& V. Nesiah (eds), Bandung, Global History and International Law: Critical Pasts and Pending Futures, Cambridge University Press, 2016.
} 
Historically inflected jurisprudence invites us to pay attention to the way in which law and jurisprudence has been written over time. ${ }^{4}$ It does not start with a single definition of law and work backwards to trace its histories. Instead our lens orients us toward seeing and describing practices which both authorize conduct, and which claim authority to speak the law, as well as the historical (and political-economic) contexts in which those practices take place. ${ }^{5}$ Such an approach enables us to recover the different ways in which the role of international law in the global order has been and may be understood by different people and at different times. ${ }^{6}$ It also enables us to see the historical struggles that lie beneath seemingly stable doctrines, rules and forms, what is required to 'stabilize' those formations in an ongoing way, and what might be at stake in that stabilization.

What we see when we re-read the Anglo-Iranian Oil Company Case through the lens of historically inflected jurisprudence is at least twofold. First, we see that Iran sought to conduct itself in a lawful way, whereas Britain, with the support of the United States, did not. Britain's response to the ICJ's decision, which supported Iran's position that the Court did not have jurisdiction to deal with the merits of the case, was to resort to force to 'repossess' Iranian oil, and to orchestrate a coup with the assistance of the United States to depose the parliamentary nationalist Mohammad Mossadeq. ${ }^{7}$ The consequences of British and American actions in Iran in the 1950s have cast long shadows, not only in Iranian political history, but also in the structuring of the international investment regime, and the militarization of resource disputes in the Middle East. Second, when we look 'slant' ${ }^{\prime}$ at this seemingly rather dry procedural dispute over whether the Court had the power to issue an interim protective order in a case where its jurisdiction to hear the merits was at issue, we can see a kaleidoscope of disputed visions of what the role of the ICJ in the world might, could and should be, at a crucial moment in the Court's formation. While these competing visions of the role of the Court may have fallen out of view for those who regard international legal decisions

\footnotetext{
${ }^{4}$ For a recent example of how this attention might be paid, see A. Genovese \& S. McVeigh, 'Nineteen Eighty Three: A Jurisographic Report on Commonwealth v Tasmania,' 24 Griffith Law Review 2015, pp. 68-88.

${ }^{5}$ These are practices we might call practices of jurisdiction, using an older, wider meaning of the term than that assumed in its narrower, technical usage since the late twentieth century. See S. Dorsett \& S. McVeigh, Jurisdiction, Routledge, 2012; S. Dorsett \& I. Hunter, (eds), Law and Politics in British Colonial Thought: Transpositions of Empire, Palgrave Macmillan, 2010; P. Rush, 'An Altered Jurisdiction: Corporeal Traces of Law,' 6 Griffith Law Review 1997, pp. 144-168; S. Pahuja, 'Laws of Encounter: A Jurisdictional Account of International Law', 1 London Review of International Law 2013, pp. 63-98.

${ }^{6}$ On this point, see S. Dorsett \& S. McVeigh, 'Jurisprudences of Jurisdiction: Matters of Public Authority', 23 Griffith Law Review 2014, pp. 570-71.

${ }^{7}$ The CIA officially admitted its role in the 1953 coup in 2013. See M. Byrne, 'CIA Admits It Was Behind Iran's Coup,' Foreign Policy, August 19, 2013, available at http://foreignpolicy.com/2013/08/19/cia-admits-it-was-behind-irans-coup/. The UK Government is yet to do so. For just one detailed account of this story by an eminent historian who revisited the story in 2004 and 2006, drawing on newly available documents and discussions and correspondence with four former British Officials involved with the events of 1951-53, see W. Roger Louis, 'Mussadiq, Oil and the Dilemmas of British Imperialism', chapter 28 in Ends of British Imperialism: The Scramble for Empire, Suez and Decolonization, Tauris, 2006. This chapter was originally published as W. Roger Louis, 'Britain and the Overthrow of the Mosaddeq Government', in M. J. Gasiorowski \& M. Byrne (eds) Mohammad Mosaddeq and the 1953 Coup in Iran, Syracuse University Press, 2004, pp. 126-77.

${ }^{8}$ We refer here to the poem by Emily Dickinson, 'Tell All the Truth but Tell It Slant.'
} 
as the best approximation of justice that can be struck in a politically volatile system, or even as simply 'good enough' for the world today, they remain present to those who have come habitually to regard those same decisions as manifestations of an enduring Eurocentric bias in international law. ${ }^{9}$

In this chapter, we begin by offering a story of the background to the dispute between the Iranian Government under Prime Minister Mossadeq and the Anglo-Iranian Oil Company, ${ }^{10}$ which led the United Kingdom to commence an action in the ICJ. In Section 3, we describe the legal dispute, the form it took and the two decisions of the ICJ which flowed from it. In Section 4, we describe the events that followed, and the implications of our redescription for understanding both this particular case, and to some extent, the relationship between Iran and international law in historical context, as urged upon us by Djamchid Momtaz. We conclude with some brief reflections on what an historically inflected jurisprudential lens might offer to scholarly practice and to our understandings of international law more broadly.

\section{Background to the dispute}

Beginnings are generally either arbitrary or mythic, and beginning our story with the grant of the infamous D'Arcy Concession of 1901 could go either way. In 1901, the Persian empire was a socio-political entity with a history of over two millennia, although its status in the European law of nations was unclear. European companies had been formed to exploit Persian oil deposits from the mid-nineteenth century, ${ }^{11}$ putatively authorized by the legal device of the 'concession'. ${ }^{12}$ Yet the concession granted to English mining entrepreneur William Knox D'Arcy by the Persian Government of Amin al-Sultan under the auspices of Qajar ruler, Muzzafer al-Din Shah,

\footnotetext{
${ }^{9}$ A third thread which is worth unravelling through this lens is the company-state relation. We omit it here for reasons of space, but will address it in a forthcoming essay explicitly situating the case in a Cold War context.

${ }^{10}$ The Anglo-Iranian Oil Company was known as the Anglo-Persian Oil Company until 1935, when 'Persia' became 'Iran'. In 1954, after the events described here, Anglo-Iranian was renamed the British Petroleum Company. The company currently trades as BP Global. For the company's public version of the events described in this chapter, see the website of BP Global; 'Post War,' available at http://www.bp.com/en/global/corporate/about-bp/our-history/post-war.html.

${ }^{11}$ R.W. Ferrier, The History of the British Petroleum Company: Volume 1 The Developing Years 1901 1932, Cambridge University Press, 2009, pp. 24-27. This is the authorised history of the Company and is read as such.

${ }^{12}$ The precise nature of the 'concession' in international law remains unclear and highly contested. It usually denotes a contract between a ruler or public authority with a foreign company or State to exercise both commercial and 'public' functions in a given area, often enormous. It was a favoured colonial instrument for two centuries, and taken up by the petroleum industry in the early twentieth century. It is a term which fell out of favour in the era of decolonisation. For a statement as to the conceptual difficulties of defining the concession in international law, see Saudi Arabia v Arabian American Oil Company (Aramco Arbitration), 'Award', ILR 1963, p. 117. For an overview and account of contests over the meaning and legality of concessions, see M. Sornarajah, The International Law on Foreign Investment, $3^{\text {rd }}$ ed., Cambridge University Press, 2010, pp. 38-41. For an account of the terminology used today to apportion rights in functional modes not dissimilar to the older concession agreement (such as production sharing agreements, joint ventures, public-private partnerships, service contracts and so on), see C. Ohler, 'Concessions', in Max Planck Encyclopedia of Public International Law. Oxford University Press. Last modified February, 2013, available at http://opil.ouplaw.com/view/10.1093/law:epil/9780199231690/law9780199231690-e1512?rskey=S34v0A\&result=4\&prd=EPIL, accessed August 23, 2016.
} 
was certainly notable for its sheer scale: D'Arcy was granted the 'special and excusive privilege to search for and obtain, exploit, develop, render suitable for trade, carry away and sell' oil and gas 'throughout the whole extent of the Persian Empire for a term of sixty years', in exchange for a lump sum of sterling, paid-up shares to the value of $£ 20,000$ in the company formed to exercise the concession, and royalty payments of $16 \%$ of annual profits. ${ }^{13}$

The granting of the D'Arcy Concession is often cited as a contributing factor in what has subsequently become known as the Iranian Constitutional Revolution of 1905, a movement which disputed the authority of the Qajar Shahs to represent Persia in agreements, and to create and grant rights such as those contained in the D'Arcy Concession. ${ }^{14}$ The Constitutional Revolution resulted in the formation of the Majlis, the Iranian parliament. ${ }^{15}$ The D'Arcy Concession, however, remained on foot. Following the Anglo-Russian Entente of 1907 in which Britain and Russia agreed, without the involvement of the Shah or the Majlis, to divide Iranian territory into respective spheres of influence, the Anglo-Persian Oil Company was incorporated in London in 1909 with the close involvement of the British imperial Government after the discovery of commercial quantities of oil. ${ }^{16}$ Anglo-Persian became the first large scale oil operation in the Middle East. ${ }^{17}$ In 1921, the Qajar dynasty was overthrown, preventing the ratification of the 1919 Anglo-Iranian Treaty that would have rendered Persia a British protectorate in international law; and Reza Khan became the first Shah of the Pahlavi dynasty in $1925 .^{18}$

The relationship between the Anglo-Persian Oil Company and the British imperial Government was symbiotic from the time of its formation. In 1914, the Company secured a contract to supply fuel oil to the Royal Navy at a fixed below-market price, and the British Government acquired a majority shareholding. ${ }^{19}$ The Company involved itself both overtly and covertly in Iranian politics, seeking to monopolize both the oil industry and Iran's foreign relations in the south, against Russian attempts to do the

\footnotetext{
${ }^{13}$ Sornarajah, supra, note 12 , p. 42 . Despite the phrasing of the Concession, the arrangement was understood by both parties to exclude the five northern provinces, the traditional areas of Russian influence. See also A. W. Ford, The Anglo-Iranian Oil Dispute of 1951-1952: A Study of the Role of Law in the Relations of States, University of California Press, 1954, p. 15.

${ }^{14}$ N. Keddie \& M. Amanat, 'Iran under the Later Qājārs, 1848-1922', in P. Avery, G. Hambly \& C. Melville (eds), The Cambridge History of Iran, vol. 7, Cambridge University Press, 1991, pp. 202-203. See also E. Abrahamian, Iran Between Two Revolutions, Princeton University Press, 1982, p. 74 et seq. Other unpopular and potentially unauthorised economic policies pursued by Muzaffer al-Din Shah reportedly included granting road tolls to the Imperial Bank of Britain, and the assumption of several loans including borrowing money from French companies to buy arms, from Russia to replay previous loans, and from Britain to finance personal ('medical') travel to Europe.

${ }^{15}$ Ferrier, supra, note 11, p. 203; for detail on the composition of the parliament, see Abrahamian, supra, note 14 , pp. 86-92.

${ }^{16}$ P. J. Beck, 'The Anglo-Persian Oil Dispute 1932-33', 9 Journal of Contemporary History 1974, p. 124. On the Anglo-Russian Entente of 1907, see M. Behravesh, 'The Formative Years of Anglo-Iranian Relations (1907-1953): Colonial Scramble for Iran and Its Political Legacy', 21 Digest of Middle East Studies 2012, pp. 388-89.

${ }^{17}$ Ferrier, supra, note 11, p. 107.

${ }^{18}$ Behravesh, supra, note 16 , p. 391.

${ }^{19}$ R. W. Ferrier, 'The Iranian Oil Industry,' in Avery, Hambly and Melville, Cambridge History of Iran, 642.
} 
same in the north. ${ }^{20}$ The extent to which the Company was involved in the ascendance of the Pahlavi dynasty remains historically contentious. ${ }^{21}$ Yet it is clear that as domestic political movements in the first half of the twentieth century sought to build a modern Iranian State that would shift the weight of sovereignty away from the Persian Shahs and toward a democratically constituted Majlis, the Anglo-Persian Oil Company sought to use its position to secure political outcomes that would favour its profit margin and the interests of its majority shareholder, the British Government. ${ }^{22}$ Supporters of the Company maintained then - as now - that those interests were consistent with the interests of the Iranian people: royalty payments from the Company's operations were the Government's main source of income, and the Company developed the industrial infrastructure of significant regions of the country. ${ }^{23}$ Yet within Persia, critics of the Company maintained that the interests of the Iranian people and of the fledgling Iranian State were chronically subordinated to the interests of the Company, and of the British empire, in the exploitation of Persian oil. ${ }^{24}$

A key critic of the Company was Mohammad Mossadeq, a legal academic elected to the first Majlis who advocated a constitutionally grounded Iranian nationalism. Popularly held as the first Iranian to receive a doctorate in law from a European university, ${ }^{25}$ Mossadeq had in 1914 written and self-published a monograph calling for the abolition of the capitulation treaties in Persia in order to strengthen Persia's territorial sovereignty. ${ }^{26}$ In 1928, as Reza Shah pursued a program of State modernization that sought both to maintain British support for the Pahlavi regime and to placate the nationalist movement in the Majlis in which Mossadeq was becoming increasingly central, the Shah abolished the British capitulation treaties and made a formal request to the Company to renegotiate the terms of the D'Arcy Concession. ${ }^{27}$ The onset of the Great Depression in Europe and the United States and resulting fall in Company profits exacerbated the key issues which the Iranians sought to address: on its own terms, the Concession was unfair, and the $16 \%$ royalty manifestly inadequate. Added to these

\footnotetext{
${ }^{20}$ Behravesh, supra, note 16, pp. 391-392; Abrahamian, supra, note 14, p. 110.

${ }^{21}$ See for example Ford, supra, note 13, pp. 12-14; A. Saikal, 'Iranian Foreign Policy 1921-79', P. Avery, G. Hambly \& C. Melville (eds), in The Cambridge History of Iran, vol. 7, Cambridge University Press, 1991, pp. 429-431; and Behravesh, supra, note 16, pp. 391-392.

${ }^{22}$ N. Abdelrehim, 'Rethinking 'Oil Nationalism': The Case of the Anglo-Iranian Oil Company', 4 International Journal of Signs and Semiotic Systems 2015, pp. 34-49.

${ }^{23}$ See for example L. Lockhart, 'The Causes of the Anglo-Persian Oil Dispute', 40 Journal of the Royal Central Asian Society, 1953, pp. 134-50; and BP Global, supra, note 10.

${ }^{24}$ Keddie \& Amanat, supra, note 14, p. 435; Abrahamian, supra, note 14, pp. 143-44.

${ }^{25}$ Mossadeq studied at Sciences Po in Paris, and Neuchâtel in Switzerland. J. A. Bill \& W. Roger Louis, 'Introduction,' in J. A. Bill \& W. Roger Louis Tauris (eds), Mussaddiq, Iranian Nationalism and Oil, 1988 , p. 3

${ }^{26}$ R. Mottahedeh, The Mantle of the Prophet: Religion and Politics in Iran, Simon and Schuster, 1985; A. Pirzadeh, Iran Revisited: Exploring the Historical Roots of Culture, Economics, and Society, Springer, 2016, p. 208. For an analysis of the function of capitulation treaties in the Ottoman context, see U. Özsu, 'Ottoman Empire', in A. Peters \& B. Fassbender (eds), Oxford Handbook of the History of International Law, Oxford University Press, 2012, pp. 429-448; and generally M. Craven, 'What Happened to Unequal Treaties? The Continuities of Informal Empire', 74 Nordic Journal of International Law 2005, pp. 335382.

${ }^{27}$ Keddie \& Amanat, supra, note 14, p. 435; Behravesh, supra, note 16, p. 392.
} 
formal iniquities, the Company was using accounting practices that limited its on-paper profit in order to reduce the sum of royalties it owed to Iran. ${ }^{28}$

As protracted negotiations took place between the Iranian Government and the Company over the terms of the Concession, in September 1932 the Majlis and Senate ratified the Government's 1930 Declaration submitting to the jurisdiction of the Permanent Court of International Justice (PCIJ). Made under Article 36, paragraph 2 of the Statute of the PCIJ on condition of reciprocity, the Declaration recognized the compulsory jurisdiction of the Court in disputes arising 'with regard to situations or facts relating directly or indirectly to the application of treaties or conventions accepted by Persia and subsequent to the ratification of this declaration'. ${ }^{29}$ The Declaration excluded inter alia any 'dispute with regard to questions which, by international law, fall exclusively within the jurisdiction of Persia'. ${ }^{30}$ In November 1932, the D'Arcy Concession was cancelled by the Iranian Government at the direction of the Shah. ${ }^{31}$ In response, the British Cabinet authorized an appeal to the Council of the League of Nations on the basis of the right of diplomatic protection, seemingly without consultation with the Company, a decision indicative of the imbrication of company and State. ${ }^{32}$ In February 1933, both Governments agreed to suspend all proceedings before the Council of the League, so that the Company and the Iranian Government could renegotiate the terms of the oil concession. In April 1933, a new Concession agreement with refined royalty and dispute resolution provisions was signed by the Iranian Government and ratified by the Majlis. In October, the Rapporteur declared to the Council of the League that 'the dispute between His Majesty's Government in the United Kingdom and the Imperial Government of Persia is now finally settled'. ${ }^{33}$ This assessment proved premature.

In 1935, Reza Shah requested that the name 'Iran' be used in place of the exonym 'Persia' in all diplomatic relations, and shortly after the Company name was amended to Anglo-Iranian. ${ }^{34}$ Although relations with Britain were formally restored following entry into the 1933 Concession, the Shah worked to develop international relationships with 'third powers' as both a bulwark against the imperial interests of the United Kingdom and the Soviet Union in Iranian territory, and a means of building international recognition of Iran as an independent nation. ${ }^{35}$ Both the United States and Germany were approached. While the increasingly autocratic Shah succeeded only in establishing limited trade and diplomatic links with the US due to Soviet protest, a tactical

\footnotetext{
${ }^{28}$ J. Bamberg, The History of The British Petroleum Company, Volume 2: The Anglo-Iranian Years, 1928-1954, Cambridge University Press, 1994, pp. 22-26. The price at which the oil was being sold to the British Government (its majority shareholder) was also very low, further reducing profits and royalties to Iran.

${ }^{29}$ The text of the Declaration, written in French, is provided in English translation in the ICJ's judgment of 22 July 1952. Anglo-Iranian Oil Company Case, supra, note 3, p. 103.

${ }^{30}$ Ibid.

${ }^{31}$ Bamberg, supra, note 28, p. 33.

32 Ibid.

${ }^{33}$ Anglo-Iranian Oil Company Case, supra, note 3, p. 111.

${ }^{34}$ It is noteworthy that the British Government continued to refer to Iran as Persia, it seems well into the 1950 's and beyond, particularly in intra-British conversations and correspondence. This was no doubt irritating and quite possibly experienced as insulting by the Iranian Government. See Ford, supra, note 13, pp. 54-55.

${ }^{35}$ Saikal, supra, note 21, pp. 433-434.
} 
relationship was formed with the National Socialist Government in Germany. By the late 1930s, a significant portion of Iran's foreign trade was with Germany, and on the outbreak of war, Iran declared its neutrality. ${ }^{36}$ The Shah's attempt to manoeuvre in European 'balance of power' politics was thwarted when Germany invaded the Soviet Union in June 1941. In the resulting Soviet-British alliance, Iran was occupied by Soviet armed forces in the north, and British armed forces in the south, essentially along the lines drawn by the Anglo-Russian Entente of 1907, while both imperial powers officially committed themselves to 'respect the sovereignty and territorial integrity' of Iran. ${ }^{37}$ The invasion ruptured Reza Khan's autocratic hold on political power, and in September 1941, he was forced to abdicate. ${ }^{38}$ Reza Khan's son Muhammad Reza Pahlavi was crowned as Shah.

The new Shah was supported by conservatives in the Majlis, but politically rejected by the growing nationalist movement, organized from 1949 as the National Front of Iran. ${ }^{39}$ This domestic instability was exploited by both the British and the Russians. The British sought to bolster pro-British sentiment within the conservative opposition to the nationalist movement, whilst the Russians sought to foster pro-Soviet agitation within the banned Iranian communist movement, incorporated during the war into the Hezb-e Tudeh Iran (Tudeh) party. ${ }^{40}$ By the late $1940 \mathrm{~s}$, the various political movements in Iran had adopted incommensurable positions on the continued economic dominance of the Anglo-Iranian Oil Company. The Shah and conservative supporters under General Ali Razmara advocated for the dedication of oil revenues to agricultural and industrial development, a reflection of the rise of development discourse in the international arena. The National Front under Mossadeq campaigned for nationalization of the oil industry. ${ }^{41}$ Political instability intensified on the election of Razmara as Prime Minister in 1950. In March 1951, Razmara was assassinated, and the Majlis and Senate passed the Oil Nationalisation Acts. The Acts approved the principle of nationalization of oil resources, and provided that all of the Company's rights in Iranian oil and related infrastructure would pass to a newly created National Iranian Oil Company for compensation at market rates. ${ }^{42}$ In April 1951, Mossadeq was elected Prime Minister ${ }^{43}$ and, in May, formally advised the Company of the Government's intention to implement the nationalization policy. ${ }^{44}$ As had been the case in 1932, the United Kingdom immediately commenced international legal action on the Company's behalf, and an action was commenced in the new International Court of Justice on 26 May 1951.

\footnotetext{
${ }^{36}$ Ibid., p. 434; Bamberg, supra, note 28, p. 230.

${ }^{37}$ Saikal, supra, note 21, pp. 434-436.

${ }^{38}$ Abrahamian, supra, note 14, pp. 163-165.

${ }^{39}$ Ibid., p. 252.

${ }^{40}$ Saikal, supra, note 21, pp. 434-436. Abrahamian considers the social history the Tudeh movement at length; see Abrahamian, supra, note 14, pp. 281-318.

${ }^{41}$ On the National Front, see H. Katouzian, 'Mosaddeq's Government in Iranian History: Arbitrary Rule, Democracy and the 1953 Coup', in M. J. Gasiorowski \& M. Byrne (eds), Mohammad Mosaddeq and the 1953 Coup in Iran, Syracuse University Press, 2004, pp. 1-26, p. 1-6.

${ }^{42}$ Bamberg, supra, note 28, pp. 418-419; also S. Nakasian, 'The Anglo-Iranian Oil Case: A Problem in International Judicial Process', 41 Georgetown Law Journal 1953, pp. 467-468.

${ }^{43}$ Hussein Ala served as Prime Minister immediately after the Assasination of Razmara, but only for 51 days as he could not garner the co-operation of parliament. Ford, supra, note 13, p. 52; Abrahamian, supra, note 14, pp. 266-67.

${ }^{44}$ Bamberg, supra, note 28, p. 420.
} 


\section{Summary of the case}

Against the dramatic backdrop of this struggle for independence against vested interests and imperial entitlement, the primary argument of the United Kingdom was quite simple in its construction. In its Application Instituting Proceedings lodged on 26 May 1951, the United Kingdom submitted that the Nationalisation Acts constituted a 'unilateral annulment' of the 1933 Agreement between the Imperial Government of Persia and the Anglo-Persian Oil Company; and that Iran had failed to respond to the Company's attempts to resolve the matter both under the good faith and arbitration clauses of the 1933 Agreement, and through diplomatic means via the United Kingdom. ${ }^{45}$ The UK's standing to bring the application in the ICJ on behalf of the Company was again asserted on the basis of the right of diplomatic protection. ${ }^{46}$ According to the Application, Iran had 'treated a British national in a manner not in accordance with the principles of international law and [had], in consequence, committed an international wrong against the Government of the United Kingdom'. ${ }^{47}$ The UK argued that because Iran had in September 1932 accepted the jurisdiction of the PCIJ with respect to all situations or facts that dealt directly or indirectly with the application of treaties and conventions entered into after that date, and the Application concerned the 1933 Agreement, the matter was within the jurisdiction of the ICJ. ${ }^{48}$

The UK also ran a series of alternative arguments. The first sought to bring within jurisdiction treaties of friendship and commerce entered into by the UK and Persia in 1857 and 1903, well prior to Iran's accession to the ICJ and therefore ostensibly outside jurisdiction. The UK listed every treaty of friendship and commerce Iran had entered into after 1932 that could be used to ascertain most favoured nation status as had been promised the UK in the 1857 and 1903 treaties. Of these, only treaties with Denmark, Switzerland and Turkey post-dated $1932 .^{49}$ The second alternative argument was that Iran's conduct constituted a breach of Article 36(3) of the new Charter of the United Nations, pursuant to which legal disputes between Member States should be referred to the ICJ; and the third was that Iran's conduct breached general principles of customary international law, although this argument was left undeveloped. ${ }^{50}$ By way of relief, the UK sought a declaration that the dispute was one that fell under the 1933 Agreement, and an order that Iran submit to arbitration; or in the alternative, a declaration that the execution of the Nationalisation Acts, insofar as it breached the 1933 Agreement, was contrary to international law. ${ }^{51}$ The UK reserved the right to request the Court to order

\footnotetext{
45 Anglo-Iranian Oil Company Case, 'Application Instituting Proceedings', 26 May 1951, ICJ Pleadings, p. 10.

${ }^{46}$ On the doctrine of diplomatic protection, see generally United Nations General Assembly, Report of the International Law Commission on the work of its fifty-eighth session, UN Doc. A/61/10, August 2006. The fifty-eighth session of the ILC was opened by Momtaz, who served as member of the ILC from 2000 to 2006, and President in the fifty-seventh session in 2005. On the historical use of diplomatic protection in international investment law, see generally Chapter 2 in Sornarajah, supra, note 12, especially pp. $37-$ 38.

47 'Application Instituting Proceedings', supra, note 45, p. 12.

${ }^{48}$ Ibid., p. 13.

49 Ibid., pp. 14-17.

${ }^{50}$ Ibid., p. 17.

${ }^{51}$ Ibid., pp. 8-19.
} 
provisional measures to protect the 'rights of the Government of the United Kingdom that their national, the Anglo-Iranian Oil Company, should enjoy the rights to which it is entitled'. 52

The Mossadeq Government's response to the ICJ proceeding was to continue with implementation of the Nationalisation Acts. ${ }^{53}$ Prime Minister Mossadeq and his Ministers asserted in writing to the Company, and in diplomatic engagements with the UK and the United States, that nationalization was a sovereign act entirely within Iran's domestic jurisdiction and a right not limited by private agreements beyond the obligation to make just compensation. ${ }^{54}$ The head of the Iranian Mixed Parliamentary Oil Commission appointed to oversee the nationalization process made public statements assuring 'the west' of an uninterrupted oil supply under the new National Iranian Oil Company. ${ }^{55}$

In response to the Iranian Government's actions, on 22 June 1951 the UK lodged a Request for the Indication of Interim Measures of Protection. ${ }^{56}$ The request sought an order for a series of measures that would prevent Iran from implementing the nationalization process until the merits of the case could be decided upon by the Court. Brought under Article 41 of the ICJ Statute, which states that the Court has power to indicate 'any provisional measures which ought to be taken to preserve the respective rights of either party', ${ }^{57}$ the grounds for the request were cited as 'actions involving or threatening to involve the loss of skilled personnel, interference with management or the disruption of the integrated enterprise operated by the Anglo-Iranian Oil Company' on the one hand, and 'inflammatory speeches, broadcasts and articles' on the other. ${ }^{58}$

A week later on 29 June 1951, Iranian Minister for Foreign Affairs Baqer Kazemi sent a letter to the ICJ containing a 'statement which the Imperial Government of Iran has prepared rejecting the petition submitted by the British Government' ${ }^{59}$ In stark contrast to the UK's highly technical submissions to the Court, the Kazemi letter is an elegiac appraisal of the failings of the international order and the history of British intervention in Iran. At variance with European court practice and procedure, and adopting an epistolary mode of engagement with the court, ${ }^{60}$ the letter opens with a passage of bold rhetoric:

\footnotetext{
52 Ibid., p. 19.

${ }^{53}$ Bamberg, supra, note 28, pp. 430-436.

${ }^{54}$ Anglo-Iranian Oil Company Case, 'Other Documents Submitted to the Court', pp. 684-697, especially p. 693 .

55 Ibid., pp. 688-90.

${ }^{56}$ Anglo-Iranian Oil Company Case, 'Request for the Indication of Interim Measures of Protection'.

${ }^{57}$ Statute of the International Court of Justice, art 41 (adapted from Article 41 of the Statute of the Permanent Court of International Justice).

58 'Request for the Indication of Interim Measures of Protection', supra, note 56, p. 54.

59 'Other Documents Submitted to the Court', supra, note 54, p. 672.

${ }^{60}$ For two meditations on epistolary form and court judgment, see B. Kunbor, 'Epistolary Jurisdiction of the Indian Courts and Fundamental Human Rights in Ghana's 1992 Constitution: Some Jurisprudential Lessons', 2 Law, Social Justice and Global Development, 2001, available at https://www2.warwick.ac.uk/fac/soc/law/elj/lgd/2001 2/kunbor/\#a2; and P. Goodrich, 'Epistolary Justice: The Love Letter as Law', 9 Yale Journal of Law and the Humanities, 1997, available at http://digitalcommons.law.yale.edu/yjlh/vol9/iss2/1/.
} 
'...the question is often asked by many nations, how is it that with the existence of the United Nations Organization, the Security Council and the International Court of Justice, the foundations of world peace are still shaky and insecure?...If we view this question impartially, it will become clear to us that greed and selfishness on the part of the strong to procure illicit advantages from the weak nations are to be regarded as the main causes of this instability and the insecurity which prevails at the present; and for so long as fair play and justice are not governing the relations of the strong and the weak, there can be no hope of bringing about world stability and achieving a lasting peace'. ${ }^{61}$

The letter goes on to state in narrative form the bases of Iran's argument against the UK's original Application: that Iran's acceptance of the jurisdiction of the ICJ in 1932 applied prospectively only, and excluded from the ICJ's purview any matters bearing on Iran's national sovereignty, and therefore according to Article 36 of the ICJ Statute, the case was outside jurisdiction; that its treaties of friendship with the UK predated Iran's acceptance of ICJ jurisdiction; that the 1933 Agreement between Persia and the Company was invalid; and that even if it was valid, the 1933 Agreement was between Iran and a private company, and therefore not within jurisdiction. ${ }^{62}$ Regarding the UK's Request for Interim Measures, the letter states that

'the respite given us by the Court is so short that one could not even procure the necessary visa for passports. Hence the Iranian government owing to the short respite, curtails its arguments; but earnestly hopes that the Court will not spare a moment to declare the case beyond its jurisdiction, as otherwise it would bring disappointment to the weaker nations as far as international justice and good-will are concerned'. ${ }^{63}$

The ICJ chose not to recognize the Kazemi letter as a submission to the Court in the nature of a preliminary objection to its jurisdiction. An ex parte hearing on the UK's Request for Interim Measures was held the following day on 30 June. On 5 July 1951, the ICJ issued an Order declaring that neither party should undertake any action that would prejudice the rights of the other or 'aggravate or extend the dispute'. ${ }^{64}$ On the question of its competence to issue provisional measures, the Court stated that the matter 'could not be regarded a priori to fall completely outside the bounds of international jurisdiction', which 'suffice(d) to empower the Court to entertain the Request for interim measures of protection'; and that 'the indication of such measures in no way prejudges the question of the jurisdiction of the Court to deal with the merits of the case and leaves unaffected the right of the Respondent to submit arguments against such jurisdiction'. ${ }^{65}$

In keeping with its position that the ICJ had no competence to issue interim orders, the Mossadeq Government continued with implementation of the Nationalisation Acts. In

\footnotetext{
61 'Other Documents Submitted to the Court', supra, note 54, pp. 672-673.

${ }^{62}$ Ibid., pp. 674-678.

${ }^{63}$ Ibid., p. 678.

${ }_{64}^{64}$ Anglo-Iranian Oil Company Case, 'Order of 5 July 1951', ICJ Reports 1951, p. 93-94.

${ }^{65}$ Ibid., p. 93.
} 
September 1951, the UK sought to have the Security Council enforce the ICJ's Order under Article 94(2) of the UN Charter, which gives the Council the power to 'make recommendations or decide upon measures to be taken to give effect to' judgments of the ICJ in cases of non-compliance. ${ }^{66}$ In October 1951, Prime Minister Mossadeq appeared at the United Nations to present Iran's case to the Security Council. ${ }^{67}$ Mossadeq commenced his address by stating that the Iranian population had one of the 'lowest standards of living in the world', and that under British control the oil industry had 'contributed practically nothing to the people's well-being, or to the technical progress or industrial development of the country'. ${ }^{68} \mathrm{He}$ then reiterated Iran's position that the ICJ had no competence to hear the original Application, and therefore no competence to issue provisional orders. ${ }^{69}$ The Security Council, unable to reach agreement on the question of the ICJ's jurisdiction in either the principal or the interim matter, resolved to adjourn the debate until the Court had ruled on its own competence. $^{70}$

On 22 July 1952, the ICJ delivered its judgment on the merits, holding that the Court had no jurisdiction to deal with the original Application submitted by the UK. ${ }^{71}$ In its reasons, the Court held that it had jurisdiction over Iran only by virtue of Iran's Declaration made under Article 36(2) of its Statute, which applied only to disputes relating to the application of treaties or conventions entered into by Iran after in September 1932 when the Declaration was ratified. ${ }^{72}$ Rejecting the UK's submission that the 1933 Agreement between Persia and the Company was of 'a double character', being both a concessionary contract with the Company and a treaty with the UK, the ICJ held that the Agreement was a private contract, and thus not within the jurisdiction accepted by Iran in $1932 .{ }^{73}$ The Court also rejected the UK's argument that treaties of friendship completed with Denmark, Switzerland and Turkey subsequent to Iran's acceptance of ICJ jurisdiction were sufficient to bring Iran's earlier treaties promising the UK most favoured nation status within its jurisdiction. ${ }^{74}$ The majority decision is silent on the matter of whether Iran's nationalization of its oil industry was a sovereign act and thus beyond the justiciability of the Court. ${ }^{75}$

\footnotetext{
${ }^{66}$ Article 94(2), Charter of the United Nations, provides as follows: '(i)f any party to a case fails to perform the obligations incumbent upon it under a judgment rendered by the Court, the other party may have recourse to the Security Council, which may, if it deems necessary, make recommendations or decide upon measures to be taken to give effect to the judgment'.

${ }^{67}$ Report of the Security Council to the General Assembly covering the period from 16 July 1951 to 15 July 1952, UN Doc. A/2167, 1952, pp. 17-24.

${ }^{68}$ Ibid., p. 20.

${ }^{69}$ Ibid., p. 20.

${ }^{70}$ Ibid., p. 24. Nakasian offers an analysis of the Security Council debate in Nakasian, supra, note 42, pp. 475-480.

${ }^{71}$ Anglo-Iranian Oil Company Case, supra, note 3, p. 114, (nine judges to five; Alvarez, Hackworth, Read, and Levi Carneiro JJ dissenting; separate opinion by McNair J).

${ }^{72}$ Ibid., p. 107.

${ }^{73}$ Ibid., p. 112.

${ }^{74}$ Ibid, p. 113.

75 In his Dissenting Opinion, under a subheading 'Iran's nationalization of the oil industry and the 'reserved domain' of that State', Judge Alvarez describes a shift from 'classical international law', under which a State could freely exercise sovereign rights within its 'reserved domain', and the 'new international law', in which 'the reserved domain of States has been modified and considerably reduced'. Anglo-Iranian Oil Company Case, supra, note 3, pp. 127-129.
} 


\section{Implications for analysis of international law}

Legal accounts of the Anglo-Iranian Oil Company Case typically end with the Court's decision of 22 July 1952. The case has been incorporated into the jurisprudence of both procedural international law and international investment law. ${ }^{76}$ Such decontextualized accounts are of course a familiar aspect of the traditional legal casebook. ${ }^{77}$ Yet this 'snapshot methodology ${ }^{, 78}$ common to much legal training radically dehistoricises legal memory of the significance of a case, and encourages us as lawyers to believe that authority - and legal forms - exist in the world as stable formations, rather than being produced through contested practices of authorization which require ongoing stabilization. Such 'snapshot methodology' also creates an impression of power as extrinsic, rather than intrinsic to law and the exercise of legal authority. Separating law from the world in this particular instance bolsters misconceptions around who adhered to international law and who did not in the events surrounding the nationalization of this particular oil company, and leaves uncontested wider Eurocentric mythologies about the adherence to and departure from international law in the attempted assertions of 'economic sovereignty' by decolonizing States in the twentieth century. ${ }^{79}$

Britain's response to the decision of the ICJ was to resort to extralegal force, both overt and covert. Prior to the Court's decision, Britain had declared economic sanctions against Iran. The Company withdrew all British workers from the Abadan oilfields, and Iran was blocked from accessing its assets held in British banks. ${ }^{80}$ Mossadeq entreatied other States with whom Iran had diplomatic ties to provide technical support to the new National Iranian Oil Company during the transition to national control. The United States, Sweden, Belgium, the Netherlands, Pakistan, and West Germany all refused, whilst Italy agreed. Continuing to hold that the nationalization was unlawful and that the Company's rights and interests under the Concession remained proprietary, in July 1952 after the ICJ decision, a British RAF plane forced an Italian-chartered tanker carrying Iranian oil into the waters of the British protectorate of Aden and issued an action in detinue, claiming the Italians were in unlawful possession of British property. ${ }^{81}$ In August 1952, US President Truman and British Prime Minister Churchill

\footnotetext{
${ }^{76}$ A. Orakhelashvili, ‘Anglo-Iranian Oil Company Case', in Max Planck Encyclopedia of Public International Law, Oxford University Press, Last modified October, 2007, available at http://opil.ouplaw.com.ezp.lib.unimelb.edu.au/view/10.1093/law:epil/9780199231690/law9780199231690-e93?rskey=13EZWx\&result=1\&prd=EPIL.

${ }^{77}$ See for example J. Crawford, Brownlie's Principles of Public International Law, $8^{\text {th }}$ ed. Oxford University Press, 2012, pp. 630-631; Sornarajah's account of the case is a notable exception to this tendency toward dehistorication. See Sornarajah, supra, note 12, p. 36.

${ }^{78}$ J. Faundez, Democratization, Development and Legality: Chile, 1831 - 1973, Palgrave Macmillan, 2007, p. 9.

${ }^{79}$ For an indicative account of the belief that Britain and the US were adhering to law whilst Iran was departing from it, even as the coup was being planned, see the postscript to the book by Alan Ford written in 1954, which announces 'the overthrow of Mossadegh's Government' in an 'army coup led by General Fazollah Zahedi', and ends with the conviction that 'the British and American Governments will try to extend a helping hand as quickly and tactfully as possible'. (Ford, supra, note 13, pp. 231-232).

${ }^{80}$ Bamberg, supra, note 28, pp. 457-458.

${ }^{81}$ The Supreme Court of Colony of Aden gave a decision in favor of the Company in Anglo-Iranian Oil Company Ltd v. Jaffrate [1953] 1 W.L.R. 246, which dismissed the ship master's testimony that the action was invalid as the ship entered the jurisdiction under duress with the following statement: '(n)o reasonable person could think it likely that H.M. Government in the year 1952 would try to resolve a
} 
issued a joint communiqué calling for the compensation to the Company to be arbitrated. Mossadeq responded by demanding 49 million pounds in compensation from the Company for intentional underpayment under the 1932 Concession. ${ }^{82}$

By February 1953, an anti-Mossadeq collaboration had formed between the United Kingdom, the United States, and the conservative movement in Iran, that together sought to strengthen the position of the Shah against the National Front. ${ }^{83}$ By April 1953, in a joint operation of the American Central Intelligence Agency and the British Military Intelligence Agency, action was underway to further destabilize Mossadeq, accelerating the political disintegration of the structure of the Iranian Government. ${ }^{84}$ Entering into a strategic alliance in the Majlis with the Tudeh party, the Mossadeq Government moved in 1953 to strip the Shah of his official powers, and forbade contact between the Shah and foreign officials. ${ }^{85}$ In June 1953, the US State Department approved a CIA-led coup operation, dubbed Operation Ajax. ${ }^{86}$ After a failed coup attempt and increasing socio-political volatility, on 19 August 1953 Operation Ajax succeeded. Following a nine-hour siege on Mossadeq's house that split the Iranian military, Mossadeq was arrested and charged with treason, and Muhammad Reza Shah Pahlavi was reinstated to political power in Iran with US and British support. ${ }^{87}$ The historical consequences of foreign sponsorship of the Shah's prolonged rule in Iran are far more widely known than the story of oil nationalization under Mossadeq that precipitated that sponsorship. Twenty-five years later, the movement toward Iranian independence away from dynastic rule and foreign interference first formalized in the Constitutional Revolution of 1905 had been reframed within the Islamist discourse of the Ayatollahs. ${ }^{88}$

As well as playing into a prevailing atmospherics of a law-abiding 'west' and recalcitrant Iran (if not a law-breaking 'rest'), recounting the Anglo-Iranian Oil Company Case without an attention to its historical context also smooths over the variety of views which were in play at the time about what an international court of justice should be and what it should do in the world, at a crucial moment in both the ICJ's formation and in the transition from an imperial to a putatively decolonizing

commercial dispute by what would be little short of an act of war'. See 'Anglo-Iranian Oil Co. v. Jaffrate et al.,' 47 American Journal of International Law 1953, p. 326.

${ }^{82}$ Bamberg, supra, note 28, pp. 473-476.

${ }^{83}$ For a detailed account of this alignment against Mosaddeq, see F. Azimi, 'Unseating Mosaddeq: The Configuration and Role of Domestic Forces', in M. J. Gasiorowski \& M. Byrne (eds), Mohammad Mosaddeq and the 1953 Coup in Iran, Syracuse University Press, 2004, pp. 27-101.

${ }^{84}$ As Louis points out, in 1952 British diplomats were expelled from Iran, and MI6 had handed over control of its intelligence network to the CIA. (Roger Louis, supra, note 7, p. 129).

${ }^{85}$ Abrahamian, supra, note 14, pp. 271-73.

${ }^{86}$ In 2000, the New York Times published the CIA's internal report on Operation Ajax. Central Intelligence Agency, National Security Archive, D. N. Wilber, 'Overthrow of Premier Mossadeq of Iran: November 1952 - August 1953', March 1954, available at http://nsarchive.gwu.edu/NSAEBB/NSAEBB435/, accessed August 23, 2016. For a popular history of the operation by a New York Times journalist, see S. Kinzer, All the Shah's Men: An American Coup and the Roots of Middle East Terror, Wiley and Sons, 2003.

${ }^{87}$ See M. J. Gasiorowski, 'Coup d'Etat against Mosaddeq' in M. J. Gasiorowski \& M. Byrne, Mohammad Mosaddeq and the 1953 Coup in Iran, Syracuse University Press, 2004, 256-58.

${ }^{88}$ Abrahamian, supra, note 14, pp. 530-37. 
world. Such differences inhered amongst States of all kinds, ${ }^{89}$ but were particularly potent as 'new' States 'entered' a juridical world not of their own design, and sought to engage with it in more or less syncretic ways. ${ }^{90}$ Indeed, what looks from the vantage point of today like a routine procedural dispute about interim measures and jurisdiction, warranting only a footnote in most texts, looks from the historical milieu of the case itself like a battle about the proper role and function of the international court in a radically changing world. ${ }^{91}$

For the Iran of Mosaddeq at least, the Anglo-Iranian Oil Company Case was the stage upon which its sovereignty would be performed, in the space between technical legal doctrine and political struggle. What was at issue was not simply a point of procedural jurisdiction, but the power to define what sovereignty would mean for decolonizing States, and the relationship of that concept to the question of international adjudication. As both the content and form of the letter from Kazemi to the Court make clear, to Iran a dispute between a private company and the Government was a matter for domestic resolution. Compensation was envisaged as a way of settling with the Company, but the right of a State to determine who had control of its most significant resources was understood as squarely within the purview of sovereign decision making. The idea that this new international law might not only support the international adjudication of such a dispute, but could potentially prevent the nationalization of natural resources from happening at all even before the Court had established its jurisdiction, ${ }^{92}$ was a grave disappointment of hopes for the institution of a new era in which 'fair play and justice [might] govern the relations of the strong and the weak'. ${ }^{93}$

It is more than ironic then, that sovereign statehood was the only legal form by which a socio-political entity could enter the world and take up a lawful place in it, and yet even

\footnotetext{
${ }^{89}$ For and exemplary document which gives some sense of the range of views of those behind the establishment of the court, see generally the report of the Commission headed by William Malkin, Report of the Informal Inter-Allied Committee on the Future of the Permanent Court of International Justice, reproduced in 39 American Journal of International Law, 1945 pp. 1-56. See also J. Headlam-Morley, Studies in Diplomatic History, Alfred H. King, 1930, especially chapter 2.

${ }^{90}$ On the question of syncretism and international law in the context of decolonisation, see Pahuja, supra, note 3. For a survey of 'new' States and their attitude to the ICJ, see I. F.I. Shihata, 'The Attitude of New States Toward the International Court of Justice,' 19 International Organization, 1965, pp. 203-222.

${ }^{91}$ On the project of trying to reconstruct in detail a historical milieu in order to understand the concerns animating the actors at the time, particularly in the context of understanding struggles over decolonisation, see D. Scott, 'The Temporality of Generations: Dialogue, Tradition, Criticism', 45 New Literary History 2014, p. 157-181.

92 Iran was of course not alone in arguing against the ICJ's jurisdiction to 'indicate provisional measures' under Article 41 of the Statute where its jurisdiction to hear the merits was in doubt. There was contemporaneous debate about whether the Court's interim decision was good law. See C. G. Fenwick, 'The Order of the International Court of Justice in the Anglo-Iranian Oil Company Case', 45 American Journal of International Law 1951, pp. 723-727; B. F. Brown, 'The Juridical Implications of the AngloIranian Oil Company Case', 1952 Washington University Law Quarterly 1952, pp. 384-397; and Ford, supra, note 13, p. 90. The legal threshold for jurisdiction to indicate interim measures is still not settled; it remains unclear whether the ICJ has to satisfy itself that the primary case does not a priori fall outside its jurisdiction, as held in Anglo-Iranian, or whether it has to satisfy itself that it prima facie has jurisdiction to hear the primary case, as held in Legality of Use of Force (Yugoslavia v Belgium et al.), ICJ Reports 1999, p. 124 and Armed Activities on the Territory of the Congo (Democratic Republic of the Congo v Rwanda), New Application, ICJ Reports 2002, p. 219.

93 'Other Documents Submitted to the Court', supra, note 54, p. 672.
} 
as non-European States took it up, the invocation of 'sovereignty' itself was decried as being against the (international) law of which it is a key jurisdictional form. ${ }^{94}$ Accounts which treat contestations over the ICJ's jurisdiction during this crucial moment as purely technical questions miss the texture of what were jurisprudential struggles over the kind of worlds being authored and authorized through international law in the wake of empire, and risk participating in the rituals of contemporary international law which imply that there is nothing outside Europe and the world of its making. ${ }^{95}$

\section{Conclusion}

Accounts of post-war decolonization and state-making in the non-European world, at least in international legal scholarship in English, have tended to under-emphasize the significance of the Iranian experience. It may well be that the history of Iran's status in twentieth century international law has defied ready analysis precisely because the Iranian experience of 'coming into' international law raises issues which have remained unresolved into the contemporary moment.

Djamchid Momtaz sought to remind us in 1976 that it was not possible to understand Iran's attitude to international law without being alive to the history of that relationship. Specifically, Momtaz wrote, the international legal scholar needed to be attentive to the Iranian experience of 'repeated attacks on [its] sovereignty' on the one hand, and 'its exclusion from the international community, from the inception of the League of Nations onwards, on the other'. ${ }^{96}$ It later turned out that 1976 was a moment in which Iran was poised 'between two revolutions', as Abrahamian has put it, each quite different in character. ${ }^{97}$ And from a vantage point some forty years later, with the benefit of both hindsight and documents which have become declassified since 1976, Momtaz' essay takes on a character both prescient and poignant. Its prescience lies in its observation that as a State, Iran is both porous and shunned. Its poignancy foreshadows the turn of the promise of decolonization, and post-imperial state-making more broadly, both in Iran and elsewhere, from 'romance' to 'tragedy', to paraphrase David Scott. ${ }^{98}$

In the Iranian version of that now all too familiar story, the romance of an urbane and enlightened European-trained lawyer, poised to translate the post-war promise of modernization into real political and economic independence for Iran through constitutional reform and the nationalization of the oil industry, is subverted by the geostrategic desires of empires new and old, inflamed by oil and distorted through the

\footnotetext{
${ }^{94}$ On sovereignty as a 'jurisdictional form' of European international law, see S. McVeigh \& S. Pahuja, 'Sovereignty as Promise and Loss', in C. Barbour \& G. Pavlich (eds), After Sovereignty: On the Question of Political Beginnings, Routledge, 2010.

${ }^{95}$ For the seminal critique of Eurocentric diffusionism, or the idea that Europeans are 'the makers of history', and that cultural processes tend to flow out of the European sector and toward the non-European sector over the course of history, see J.M. Blaut, The Colonizer's Model of the World: Geographical Diffusionism and Eurocentric History, Guilford Press, 1993. For an account of international law which describes the way in which administrative arrangements and legal forms moved from 'periphery' to 'centre' rather than the other way around, see C. Storr, 'End State: Nauru and the History of International Law', (doctoral thesis in progress).

${ }^{96}$ Momtaz, supra, note 1, p. 199 (our translation).

97 Abrahamian, supra, note 14.

${ }^{98}$ See D. Scott, Conscripts of Modernity: the Tragedy of Colonial Enlightenment, Duke University Press, 2004.
} 
prism of Cold War paranoia. ${ }^{99}$ The democratically elected Mossadeq dies under house arrest in 1967 after a coup orchestrated by Britain and the United States. From the British perspective, the coup was 'necessary' to reverse the nationalization of the oil industry. From the American perspective, the coup was meant to prevent the communist takeover of the Government, a belief which was almost certainly spurious as it turns out, and encouraged by Britain as a way to encourage the United States to support its own aims. ${ }^{100}$

Historically de-contextualized readings of the Anglo-Iranian Oil Company Case miss the shift from romance to tragedy which the case and its aftermath represent, and belie the way in which the case cut across matters of international ordering which were profoundly uncertain in 1951. Tensions between the 'international' jurisdiction constructed in the nineteenth century to govern the relations of imperial powers and the domestic jurisdiction of newly sovereign States formerly subject to imperial rule were becoming increasingly apparent. ${ }^{101}$ Whereas the administrative apparatus of imperial rule was largely in retreat as the movement toward formal self-determination gathered momentum, the continued operation in decolonizing States of companies founded under imperial conditions was fiercely defended by the old imperial powers. Whilst the era of formal empire was declared to be coming to an end, the fate of the economic order constructed during that era remained an open question. As newly independent States attempted to nationalize domestic resources, arguing that nationalization was in keeping with principles of sovereign equality and self-determination, foreign companies and States alike defended foreign ownership of those resources, arguing that the proper observance of contract and property rights was in keeping with principles of peace and stability. There were deeply diverging views, too, around the character of international law, and the proper role of international institutions. Different peoples had very different ideas about what kind of institution the International Court of Justice should be, and the role it should play in ordering the world. The effect of the United Nations Charter on the interpretation of the jurisprudence of the PCIJ was unclear. ${ }^{102}$ As States like Iran sought to participate as equals in the international community, profoundly political and historical questions about the meaning of decolonization and the proper

\footnotetext{
${ }^{99}$ This patterning - from the European-educated nationalist leader with faith in the constitution and the desire to nationalise economic engines previously exploited for the benefit of the coloniser - was repeated all over the Third World. The 'lessons' learned by Britain and the United States from the putative success of the Iranian venture when assessed from a short temporal horizon, were carried over into Suez and Guatemala respectively. By the end of the 1970 s, it may have seemed fairly clear to many that imperial hubris and Cold War paranoia were perhaps clouding judgments in the North.

${ }^{100}$ A. N. Rubin, Archives of Authority: Empire, Culture and the Cold War, Princeton University Press, 2012, p. 34; and Gasiorowski, supra, note 87, pp. 229-233. This story is the subject of a forthcoming essay we are writing on Iran, international law and the Cold War as part of the Australian Research Council-funded project, 'International Law and the Cold War', see http://www.coldwarinternationallaw.org/.

${ }^{101}$ See generally G. Simpson, Great Powers and Outlaw States: Unequal Sovereigns in the International Legal Order, Cambridge University Press, 2004; M. Koskenniemi, The Gentle Civilizer of Nations: The Rise and Fall of International Law 1870 - 1960, Cambridge University Press, 2002; and Dorsett \& McVeigh, supra, note 6.

102 The legal status of the general obligations listed in Article 2(2)-2(6), including the obligation to settle international disputes by peaceful means, was untested, as was the meaning of Article 2(7), which placed matters 'essentially within the domestic jurisdiction of any State' beyond UN intervention. This was a key part of the debate in the Security Council over the Anglo-Iranian case. See Nakasian, supra, note 42, pp. $475-480$.
} 
shape and role of international institutions and international laws in the world were being reframed by former imperial powers as technical questions of jurisdiction and interpretation. ${ }^{103}$ When read through the lens of historically inflected jurisprudence, the Anglo-Iranian Oil Company Case offers a significant insight into this moment of transition.

${ }^{103}$ As an iteration of an argument describing the role of technical expertise in shaping political struggles, see D. Kennedy, A World of Struggle: How Power, Law, and Expertise Shape Global Political Economy, Princeton University Press, 2016. 


\section{University Library}

\section{- M M N E R VA A gateway to Melbourne's research publications}

Minerva Access is the Institutional Repository of The University of Melbourne

Author/s:

Pahuja, S;Storr, A

Title:

Rethinking Iran and International Law: The Anglo-Iranian Oil Company Case Revisited

Date:

2017

Citation:

Pahuja, S. \& Storr, A. (2017). Rethinking Iran and International Law: The Anglo-Iranian Oil Company Case Revisited. Crawford, J (Ed.). Koroma, A (Ed.). Mahmoudi, S (Ed.). Pellet, A (Ed.). The International Legal Order: Current Needs and Possible Responses: Essays in Honour of Djamchid Momtas, (1), pp.53-74. Koninklijke Brill NV.

Persistent Link:

http://hdl.handle.net/11343/251328 